J. Appl. Glycosci., 51, 223-227 (2004)

(C) 2004 The Japanese Society of Applied Glycoscience

\title{
Production of Turanose by Cyclomaltodextrin Glucanotransferase from Bacillus stearothermophilus
}

\author{
(Received March 26, 2004 ; Accepted April 24, 2004)
}

Takashi Shibuya, ${ }^{*}$ Takahiko Mandai, Michio Kubota, Shigeharu Fukuda, Masashi Kurimoto and Yoshio Tsujisaka

Hayashibara Biochemical Laboratories, Inc. (7-7, Amase-minami machi, Okayama 700-0834, Japan)

\begin{abstract}
Cyclomaltodextrin glucanotransferase (EC 2.4.1.19, abbreviated as CGTase) from Bacillus stearothermophilus produced a series of transfer products from a mixture of cyclomaltohexaose and D-fructose. After digestion with glucoamylase, the resultant product contained turanose and trehalulose in addition to Dglucose and D-fructose. These results showed that CGTase transferred the glucose residue to the C3- and C1hydroxy groups of fructopyranose. The optimum conditions on the turanose production from $\alpha-C D$ and $D-$ fructose using CGTase were examined. The reaction mixture containing $30 \%$ of $\alpha$-CD and $30 \%$ of $\mathrm{D}$-fructose and $300 \mathrm{U} / \mathrm{g}$ of $\alpha$-CD of CGTase from B. stearothermophilus was incubated at $60^{\circ} \mathrm{C}$ and $\mathrm{pH} 5.5$ for $24 \mathrm{~h}$ and then treated with glucoamylase. Turanose was produced in a yield of about $45 \%$.
\end{abstract}

Key words: turanose, trehalulose, cyclomaltodextrin glucanotransferase, cyclomaltodextrin, transglycosylation

Cyclomaltodextrin glucanotransferase (EC 2.4.1.19, CGTase) catalyzes not only the cyclization reaction forming cyclodextrins from starch but also the transglycosylation reaction in the presence of suitable acceptors. ${ }^{1)}$ DGlucose and the oligosaccharides containing D-glucose at the non-reducing side of the oligosaccharide such as maltose and sucrose are good acceptors. The transglycosylation reaction occurs at the C4-hydroxyl group of Dglucose or glucosyl residue and forms $\alpha$-glucose- and $\alpha$ maltooligosaccharide-linked transfer products. D-Xylose and L-sorbose, which have a D-glucose-like conformation in their pyranose rings, are effective acceptors. Although D-xylose gives the transfer products linked to the C4hydroxyl group, ${ }^{2)}$ the transglycosylation to L-sorbose occurs at the C3-hydroxyl group. ${ }^{2)}$ When a large amount of CGTase was used, the transglycosylation reaction was observed in various saccharides and compounds. The transglycosylation to L-ascorbic acid occurred preferentially at the C2-hydroxyl group. ${ }^{3)} \mathrm{D}$-Galactose gave the transfer products for C1-, C3- and C2-(C4) hydroxyl groups in the ratio of $26: 10: 1$, respectively. ${ }^{4)}$ The transfer products for lactose were glucosyl lactoside $(\alpha-\mathrm{D}$ glucosyl $O-\beta$-D-galactosyl- $(1 \rightarrow 4)-\beta$-D-glucoside $)$ as a main product and $3^{\text {Gal }}-O-, 4^{\text {Gal }}-O$ - and $2^{\text {Gal }}-O-\alpha$-D-glucosyllactose as minor products. ${ }^{5,6)}$ Thiamin $^{7}$ and cathechin ${ }^{8)}$ also functioned as acceptors of the CGTase reaction. Transglycosylations to fructose by CGTases from Bacillus stearothermophilus, alkalophilic Bacillus sp. and Brevibacterium $\mathrm{sp}$. has been reported already. ${ }^{9-11)}$ The structure of transfer product, however, was not determined hitherto.

In this study, we report on the structure of the transfer product for $\mathrm{D}$-fructose and determine the linkage site of $\mathrm{D}$ -

\footnotetext{
${ }^{*}$ Corresponding author (Tel. +81-86-231-6731, Fax. +81-86-231 -6738, E-mail: amaseken@ hayashibara.co.jp).

Abbreviations: CGTase, cyclomaltodextrin glucanotransferase (EC 2.4.1.19); $\alpha-\mathrm{CD}$, Cyclomaltohexose.
}

fructose. Optimum conditions for transglycosylation products are also examined.

\section{MATERIALS AND METHODS}

Saccharides. Maltose, neotrehalose, maltotriose, maltotetraose, maltopentaose, and cyclomaltohexaose $(\alpha-\mathrm{CD})$, a commercially available reagent, were produced at our laboratory. D-Glucose, D-fructose, trehalulose, turanose, and soluble starch were purchased from Wakojunyaku Kogyo Co. (Tokyo, Japan). Dextrin (Pine dex \#1) was purchased from Matsutani Chemical Industry Co., Ltd. (Itami, Japan).

Enzymes. CGTases from B. stearothermophilus and B. circulans were prepared in our laboratory. ${ }^{12)}$ The enzyme from B. macerans from Aspergillus niger was obtained from Amano Pharmaceutical Co. (Nagoya, Japan). Glucoamylase from Rhizopus niveus was purchased from Seikagaku Kogyo Co. (Tokyo, Japan).

Assay of enzyme activity.

CGTase activity. The activity of CGTase was measured by the method of Shiosaka and Bunya. ${ }^{13)}$ The reaction mixture containing $0.2 \mathrm{~mL}$ of enzyme solution and 5 $\mathrm{mL}$ of $0.3 \%$ soluble starch in $20 \mathrm{mM}$ acetate buffer $(\mathrm{pH}$ 5.5) and $1 \mathrm{mM} \mathrm{CaCl}_{2}$ was incubated at $40^{\circ} \mathrm{C}$ for $10 \mathrm{~min}$. The reaction was stopped by adding $0.5 \mathrm{~mL}$ of the reaction mixture to $15 \mathrm{~mL}$ of $0.02 \mathrm{~N}$ sulfuric acid, and then $0.2 \mathrm{~mL}$ of $0.1 \mathrm{~N}$ iodine solution was added. The color of the solution was measured at $660 \mathrm{~nm}$. One unit of CGTase activity was defined as the amount of the enzyme that catalyzed a $10 \%$ decrease of the absorbance per min under these conditions.

Glucoamylase activity. The activity of glucoamylase was measured according to the method reported previously. ${ }^{14)}$ The reaction mixture containing $0.2 \mathrm{~mL}$ of enzyme solution and $5.0 \mathrm{~mL}$ of $1.0 \%$ soluble starch in 20 $\mathrm{mM}$ acetate buffer ( $\mathrm{pH} 5.5$ ) was incubated at $40^{\circ} \mathrm{C}$ for 10 
min. The reaction was stopped by adding $1.0 \mathrm{~mL}$ of the reaction mixture to $2.0 \mathrm{~mL}$ of Somogyi reagent. The amount of reducing sugar produced was measured by the Somogyi-Nelson method. ${ }^{15)}$ One unit of glucoamylase activity was defined as the amount of the enzyme that produces a level of reducing sugar equivalent to $1.0 \mu \mathrm{mol}$ of glucose per min under these conditions.

High-pressure liquid chromatography (HPLC). Samples were first treated by filtration using a filter kit, $\mathrm{KC}$ prep dura (0.45 $\mu \mathrm{m}$, Katayama Chemical Co., Osaka, Japan) and by deionization using a micro acilyzer G0 (Asahi Chemical Co., Tokyo, Japan). HPLC was done using a Tosoh HPLC system (Tosoh, Tokyo, Japan) composed of a CCPM pump, an AS8010 auto-sampler, and an RI-8012 refractive index flow analyzer. Sugars were separated on a YMC PA-03 $(4.6 \times 250 \mathrm{~mm})$ using a $70: 30$ mixture of acetonitrile and water as the mobile phase, at a flow rate of $0.5 \mathrm{~mL}$ per min. The yield of transfer products showed on sugar composition.

Gas liquid chromatography (GLC). After trimethylsilylation, the sample was analyzed by GLC (GC-14B, Shimadzu Seisakusho, Kyoto, Japan) in an OV-1701 capillary column $(25 \times 0.25 \mathrm{~mm}$ i.d., GL science, Tokyo, Japan) at $140-180^{\circ} \mathrm{C}\left(2^{\circ} \mathrm{C} / \mathrm{min}\right)$.

Instrumental analyses. A liquid chromatograph mass spectrometer (LC-MS) used a model LCQ advantage iontrap mass analyzer (Thermo Quest, Tokyo, Japan). HNMR and ${ }^{13} \mathrm{C}$-NMR was done in $\mathrm{D}_{2} \mathrm{O}$ using a model JNM-AL300 spectrometer (JEOL, Tokyo, Japan) at 300 and $75.45 \mathrm{MHz}$, respectively.

\section{RESULTS}

\section{Formation of saccharide $A$ and saccharide $B$.}

Transglycosylation to fructose by CGTase was examined using $\alpha-\mathrm{CD}$ as the glycosyl donor. A reaction mixture $(100 \mathrm{~g})$ containing $25 \%$ of D-fructose, $25 \%$ of $\alpha$ $\mathrm{CD}$, and $5000 \mathrm{U}$ of CGTase from B. stearothermophilus in $50 \mathrm{~mm}$ acetate buffer ( $\mathrm{pH} 5.5)$ was incubated at $60^{\circ} \mathrm{C}$ for $24 \mathrm{~h}$. Figure 1(a) shows an HPLC chromatogram of the resultant reaction mixture was analyzed using an YMC PA-03 column. A series of transfer products were formed in addition to D-fructose and D-glucose.

To hydrolyze the $\alpha$-1,4-glucan chains of the transfer products, digestion by glucoamylase was done as follows: the CGTase-reaction mixture (45 g) was added to $135 \mathrm{~g}$ of $50 \mathrm{mM}$ acetate buffer $(\mathrm{pH} 4.5)$ containing $900 \mathrm{U}$ of glucoamylase, and then incubated at $40^{\circ} \mathrm{C}$ for $24 \mathrm{~h}$. Figure 1(b) shows an HPLC chromatogram of the hydrolyzate. The HPLC profile was rather simple and showed only four components present, which were D-fructose, Dglucose, saccharide $\mathrm{A}$ and saccharide $\mathrm{B}$, of which the contents were 22.2, 19.6, 44.0 and $9.8 \%$, respectively. The contents of saccharide A and saccharide B were increased by the glucoamylase-treatment, meaning that the transfer products linked to the $\alpha$-1,4-glucan chain coexisted with saccharide $\mathrm{A}$ and $\mathrm{B}$.

Isolation of saccharide A.

Saccharide A was isolated from the reaction mixture after glucoamylase digestion using a preparative ODS col-
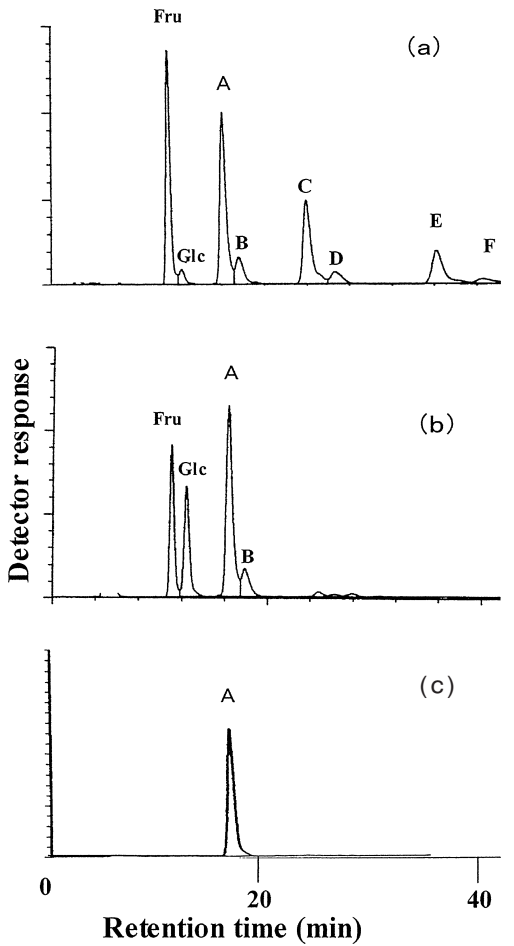

Fig. 1. HPLC profiles of the reaction mixture.

(a) $\alpha$-CD and fructose-derived products after glycosyl transfer catalyzed by CGTase. Glc, glucose; Fru, fructose; A, saccharide A; B, saccharide B; C, saccharide C; D, saccharide D; E, saccharide E; F, saccharide F. (b) Hydrolyzate catalyzed by glucoamylase. Glc, glucose; Fru, fructose; A, saccharide A; B, saccharide B. (c)Purified saccharide A.

umn $(4.6 \times 250 \mathrm{~mm}$, YMC-Pack ODS-AQ-303). When the solution of saccharide A was concentrated up to $75 \%$ and methanol was added up to $75 \%$ of the final concentration, crystals of saccharide A were formed. The purified saccharide A was obtained $2.8 \mathrm{~g}$ (Fig. 1(c)). Saccharide A was identified by HPLC and GLC (data not show) with authentic turanose. Spectrograms of $\mathrm{H}-\mathrm{NMR}$ and ${ }^{13} \mathrm{C}$ NMR of saccharide A completely agreed with those of turanose (data not show). We, therefore, concluded that saccharide $\mathrm{A}$ is turanose ( $\alpha$-D-glucopyranosyl-( $1 \rightarrow 3)-\alpha-\mathrm{D}$ fructose).

\section{Saccharide $B$.}

LC-MS analysis gave an ion $(\mathrm{M}+\mathrm{Na})^{+}$at $\mathrm{MS} \mathrm{m} / \mathrm{z} 365$ for saccharide $\mathrm{B}$, meaning that saccharide $\mathrm{B}$ is a disaccharide consisting one molecule of $\mathrm{D}$-glucose and one molecule of D-fructose. As compared with various forms of $\alpha$ D-glucosyl-D-fructose, the retention time of saccharide B by HPLC agreed with that of trehalulose ( $\alpha$-Dglucopyranosyl-( $1 \rightarrow 1)-\alpha$-D-fructose). GLC analysis also showed the same retetion time for saccharide B as that for trehalulose. Saccharide B was not purified, but it is clear that this saccharide is trehalulose.

Thus, CGTase catalyzes the transglycosylation reaction to D-fructose, and produces turanose and trehalulose in a ratio of $9: 2$. The transfer sites of $\mathrm{D}$-fructose were the C3- and C1-hydroxyl groups.

Effects of CGTase concentrations on the production of turanose.

The effects of a range of concentrations of CGTase 
(20-1000 U/g of $\alpha-\mathrm{CD})$ on transglycosylation were examined. The CGTase reactions were done using $25 \%$ of D-fructose and $25 \% \alpha-\mathrm{CD}$ at $\mathrm{pH} 5.5$ and $60^{\circ} \mathrm{C}$, for $24 \mathrm{~h}$. The reaction mixture was treated with glucoamylase as described above. The resultant saccharide contents are listed in Table 1. The turanose content reached $44.3 \%$ with $300 \mathrm{U} / \mathrm{g}-\alpha-\mathrm{CD}$ of the enzyme concentration, and seemed to decrease slightly with excess amounts of the enzyme (400 and $1000 \mathrm{U} / \mathrm{g}-\alpha-\mathrm{CD}$ ). On the other hand, the content of trehalulose and other transfer products were produced by the excess amounts of the enzyme, especially $1000 \mathrm{U} / \mathrm{g}-\alpha-\mathrm{CD}$. LC-MS analysis showed that these products were a di-saccharide, probably neotrehalose, and tri-saccharide, but the structures of the trisaccharide were not determined in this study.

\section{Comparison with other CGTases.}

In addition to the CGTase from $B$. stearothermophilus (an intermediate type between $\alpha$ - and $\beta$-CD-forming enzyme), the enzymes from $B$. macerans ( $\alpha$-CD-forming enzyme) and $B$. circulans ( $\beta$-CD-forming enzyme) were tested for catalysis of transglycosylation to fructose. As shown in Table 2, both CGTases also produced turanose and trehalulose, but the yields of turanose and trehalulose were low compared to that from B. stearothermophilus CGTase when the enzyme concentration used was $200 \mathrm{U} /$ g- $\alpha$-CD. The enzymes from B. stearothermophilus and $B$. circulans produced turanose and trehalulose in the ratio of about $4: 1$, but the enzyme from $B$. macerans gave a ratio of about $2: 1$, suggesting that the enzyme from $B$.

Table 1. Effects of CGTase concentrations on the production of turanose.

\begin{tabular}{rccccc}
\hline \multirow{2}{*}{$\begin{array}{c}\text { CGTase } \\
(\mathrm{U} / \mathrm{g})\end{array}$} & \multicolumn{5}{c}{ Sugar composition $(\%)$} \\
\cline { 2 - 6 } & Glucose & Fructose & Turanose & Trehalulose & Others \\
\hline 20 & 33.3 & 38.2 & 24.2 & 4.3 & 0.0 \\
50 & 27.0 & 34.9 & 31.3 & 6.1 & 0.5 \\
100 & 24.1 & 31.9 & 35.1 & 7.7 & 1.2 \\
200 & 21.3 & 26.6 & 41.2 & 8.7 & 2.2 \\
300 & 20.0 & 23.6 & 44.3 & 9.3 & 2.8 \\
400 & 21.2 & 23.2 & 43.1 & 9.4 & 3.1 \\
1000 & 19.7 & 20.6 & 41.5 & 11.9 & 6.3 \\
\hline
\end{tabular}

The reaction mixture $(5 \mathrm{~g})$, containing $1.25 \mathrm{~g}$ of $\alpha-\mathrm{CD}$ and 1.25 $\mathrm{g}$ of fructose, and from 20 to $1000 \mathrm{U}$ of CGTase from B. stearothermophilus, was incubated at $60^{\circ} \mathrm{C}$ and $\mathrm{pH} 5.5$ for $24 \mathrm{~h}$. The yields of glucoamylase-resistant molecules, glucose, fructose, turanose, trehalulose and others (unknown saccharides) were measured by HPLC. macerans tends to transfer glucosyl residues to the $\mathrm{C} 1$ hydroxy group of D-fructose in comparison with the $B$. stearothermophilus and B. circulans enzymes.

\section{Glycosyl donor.}

We tested various saccharides as donor substrates for transglycosylation to D-fructose. D-glucose, maltose, maltotriose, maltotetraose, maltopentaose, dextrin (DE 5\%), soluble starch and $\alpha$-CD were used as the donor substrates. The CGTase reactions $(200 \mathrm{U} / \mathrm{g}-\alpha-\mathrm{CD})$ were done using $25 \%$ of $\mathrm{D}$-fructose and $25 \%$ of donor at $\mathrm{pH}$ 5.5 and $60^{\circ} \mathrm{C}$, for $24 \mathrm{~h}$. The reaction mixtures were treated with glucoamylase as described above. Figure 2 shows the yields of turanose from the donor substrates. Among the substrates tested in this study, $\alpha-\mathrm{CD}$ was the best substrate yielding $43.7 \%$ of turanose. Next to $\alpha-\mathrm{CD}$, soluble starch and dextrin produced 34.2 and $31.5 \%$ of turanose, respectively. Linear maltooligosaccharides gave turanose according to the number of glucose residues of maltooligosaccharides, but the yields of turanose were less than $30 \%$.

\section{Effects of substrate concentrations on the production of turanose.}

The effects of concentrations of substrate on transglycosylation were tested. The CGTase reactions $(200 \mathrm{U} / \mathrm{g}-\alpha-$ CD) were done using $8.5^{-32.5 \%}$ of D-fructose and 8.5$32.5 \%$ of $\alpha-\mathrm{CD}$ at $\mathrm{pH} 5.5$ and $60^{\circ} \mathrm{C}$, for $24 \mathrm{~h}$. The reaction mixtures were treated with glucoamylase as described above. Figure 3 shows the relationship of the total sub-

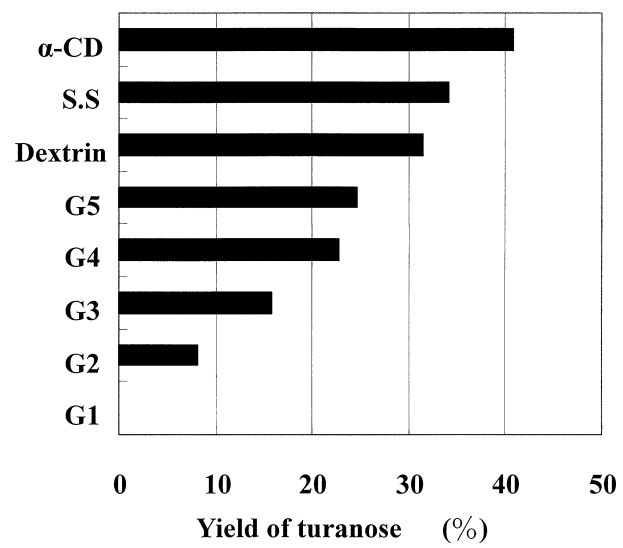

Fig. 2. Effects of substrate degree on the production of turanose.

G1, glucose; G2, maltose; G3, maltotriose; G4, maltotetraose; G5, maltopentaose Dextrin, pine-dex \#1; S.S, soluble starch; $\alpha$-CD, cyclomaltohexaose.

Table 2. Production of turanose by other CGTases.

\begin{tabular}{lccccr}
\hline \multirow{2}{*}{ Origin } & \multicolumn{5}{c}{ Sugar composition (\%) } \\
\cline { 2 - 6 } & Glucose & Fructose & Turanose & Trehalulose & Others \\
\hline Bacillus stearothermophilus & 26.6 & 21.3 & 41.2 & 8.7 & 2.2 \\
Bacillus circulans & 41.2 & 38.1 & 17.1 & 3.3 & 0.3 \\
Bacillus macerans & 42.5 & 41.1 & 10.5 & 4.9 & 1.0 \\
\hline
\end{tabular}

The reaction mixture $(5 \mathrm{~g})$, containing $1.25 \mathrm{~g}$ of $\alpha-\mathrm{CD}$ and $1.25 \mathrm{~g}$ of fructose, and $200 \mathrm{U}$ of CGTase from $B$. stearothermophilus, B. macerans and B. circulans was incubated at $60^{\circ} \mathrm{C}$ and $\mathrm{pH} 5.5$ for $24 \mathrm{~h}$. The yields of glucoamylase-resistant molecules, glucose, fructose, turanose, trehalulose and others (unknown saccharides) were measured by HPLC. 
strate concentration and yield of turanose. The yields of turanose slightly increased as the substrate concentrations increased. The highest concentration (65\%) gave $43.7 \%$ of turanose.

\section{Effects of the ratios of fructose to $\alpha-C D$.}

We investigated the formation of turanose using different substrate ratios of $\mathrm{D}$-fructose to $\alpha-\mathrm{CD}$ (Table 3 ). Turanose yield reached $44.0 \%$ when the concentration of D-fructose (25\%) was equal to that of $\alpha$-CD (25\%). The yield of trehalulose was a maximum $(9.9 \%)$ in the $\alpha-\mathrm{CD}$ rich substrate ; $\alpha-\mathrm{CD}$ : $\mathrm{D}$-fructose $=33.3$ : 16.7. Other transfer products increased as the ratio of $\mathrm{D}$-fructose decreased. A main component of other transfer products was probably neotrehalose.

\section{DISCUSSION}

It is known that CGTase catalyzes the transferring of $\alpha$-1,4-glucan chains to the C4-hydroxyl groups of Dglucose. From analysis of the derivatives of D-glucose, Kitahata et al. reported that the configuration of the $\mathrm{C} 2-$, C3-, C4-hydroxyl groups of D-glucose was the key structure for the transglycosylstion of CGTase. ${ }^{1)}$ We studied

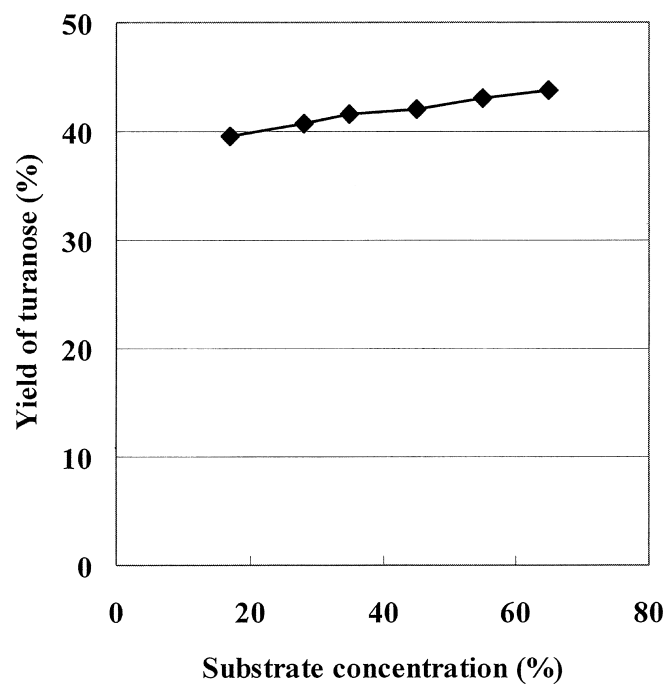

Fig. 3. Effects of substrate concentrations on the production of turanose.

Table 3. Effects of donor/acceptor ratios on the production of turanose.

\begin{tabular}{lcrrrrr}
\hline \multirow{2}{*}{$\begin{array}{c}\alpha-\mathrm{CD} \\
(\%)\end{array}$} & $\begin{array}{c}\text { Fructose } \\
(\%)\end{array}$ & \multicolumn{5}{c}{ Sugar composition $(\%)$} \\
\cline { 3 - 7 } & & Glucose & Fructose & Turanose & Trehalulose & Others \\
\hline 40 & 10.0 & 51.3 & 3.0 & 21.8 & 7.5 & 16.4 \\
37.5 & 12.5 & 44.8 & 4.1 & 27.1 & 9.2 & 14.8 \\
33.3 & 16.7 & 37.5 & 7.6 & 35.4 & 9.9 & 9.6 \\
25.0 & 25.0 & 22.2 & 19.6 & 44.0 & 9.8 & 4.4 \\
16.7 & 33.3 & 13.4 & 39.5 & 38.0 & 7.2 & 1.9 \\
12.5 & 37.5 & 10.1 & 52.5 & 31.4 & 5.8 & 0.2 \\
10.0 & 40.0 & 9.3 & 59.0 & 26.2 & 4.7 & 0.8 \\
\hline
\end{tabular}

The reaction mixture $(5 \mathrm{~g})$, containing $3.0 \mathrm{~g}$ of $\alpha-\mathrm{CD}$ and fructose, and from $200 \mathrm{U} / \mathrm{g}-\alpha-\mathrm{CD}$ of CGTase from $B$. stearothermophilus was incubated at $60^{\circ} \mathrm{C}$ and $\mathrm{pH} 5.5$ for $24 \mathrm{~h}$. The yields of glucoamylase-resistant molecules, glucose, fructose, turanose, trehalulose and others (unknown saccharides) were measured by HPLC. glycosytransferring to D-fructose by CGTase using $\alpha-\mathrm{CD}$ as the glycosyl donor. The glycosylated sites of D-fructose were determined as the C3- and C1-hydroxyl groups of Dfructose. The main product was turanose, the glucose residue of which was linked with the C3-hydroxyl group of D-fructopyranose. When the configuration of D-fructopyranose is compared with D-glucopyranose (Fig. 4), the C5-, C4and C3-hydroxyl groups of D-fructopyranose correspond to the C2-, C3- and C4-hydroxyl groups, respectively, of D-glucopyranose. It is reasonable that the C3-hydroxyl group of D-fructopyranose, which corresponds to the C4hydroxyl group of D-glucopyranose, is the acceptor site of the transglycosylation of CGTase. Although all of these hydroxyl groups of D-fructopyranose are equatorial, the C5-hydroxy group of D-fructopyranose is axial and the C3- and C4-hydroxyl groups are equatorial. The difference in conformation of the C5-hydroxyl group between D-glucopyranose and D-fructopyranose may affect the transglycosylation. D-Mannopyranose has the D-fructopyranoselike conformation in which C2-, C3- and C4-hydroxyl groups are axial, equatorial and equatorial, respectively.

Mori et al. observed that CGTase from Brevibacterium catalyzed the transglycosylation to the C4-hydroxyl group of D-mannopyranose. ${ }^{11)}$ These results suggest that the third hydroxl group may act as the linkage site for the transglycosylation of CGTase when the successive three hydroxyls of the pyranose ring $(\mathrm{C} 5, \mathrm{C} 4$ and $\mathrm{C} 3$ in the case of Dfructopyranose) form the axial-equatorial-equatorial conformation. It is know that $\alpha$-glucosyltransferase from Pro-

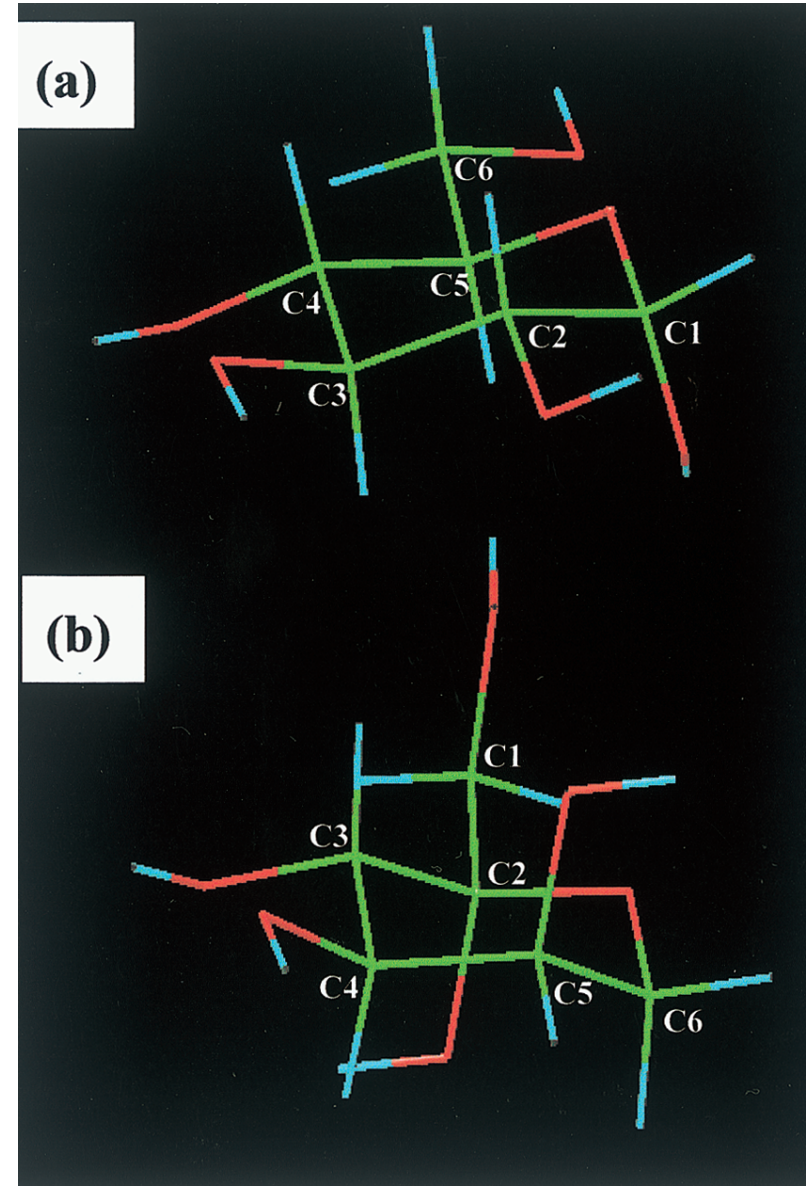

Fig. 4. Conformation of glucopyranose and fructopyranose.

(a) glucopyranose, (b) fructopyranose. 
taminobacter rubrum transfers a glucosyl residue to the C1- and C6-hydroxyl groups of D-fructose to produce trehalulose ( $\alpha$-D-glucopyranosyl-( $1 \rightarrow 1)-\alpha$-D-fructose) and palatinose $(\alpha$-D-glucopyranosyl-( $1 \rightarrow 6)$ - $\alpha$-D-fructose $).{ }^{16)}$ Our observation showed that CGTase produced trehalulose but no palatinose. D-Fructose has two primary hydroxy groups (C1 and C6) in structure of D-fructofuranose. However, Dfructopyranose has only one primary hydroxyl group (C1) in the structure. CGTase possesses the ability to transfer the D-glucose residue to the primary hydroxyl group of alcohol such as ethanol. Probably, CGTase utilizes Dfructopyranose, but no D-fructofuranose, as the acceptor for the transglycoylation, and transfers the glucosyl residue to the C1-hydroxyl group of D-fructopyranose in addition to the C3-hydroxyl group of the ring.

We determined the optimum condition for the turanose production from $\alpha-\mathrm{CD}$ and $\mathrm{D}$-fructose by CGTase. The reaction mixture consisting of $30 \%$ of $\alpha-\mathrm{CD}, 30 \%$ of $\mathrm{D}$ fructose, and $300 \mathrm{U} / \mathrm{g}-\alpha-\mathrm{CD}$ was incubated at $60^{\circ} \mathrm{C}$ and $\mathrm{pH} 5.5$ for $24 \mathrm{~h}$ and then treated by glucoamylase. Turanose was produced in a yield of $45 \%$ under the conditions. However, $\alpha-C D$ is an expensive saccharide and unsuitable for industrial production; therefore we selected starch as the glycosyl donor for the reaction. After our trial using starch and D-fructose, we demonstrated the large-scale production of turanose from starch and Dfructose by CGTase. The sweetness of turanose is half that of sucrose. Turanose inhibits the activity of $\alpha$ glucosidase. ${ }^{17)}$ Turanose may be anticipated as a new sweetener for foods, cosmetics and medicines.

\section{REFERENCES}

$1)$ S. Kitahata: Handbook of Amylases and Related Enzymes, The Amylase Research Society of Japan, ed., Pergamon Press, pp. 154-164 (1988).

2 ) S. Kitahata and S. Okada: Enzymatic synthesis of 3-O- $\alpha$-Dglucopyranosyl-L-sorbose and 4- $O$ - $\alpha$-D-glucopyranosyl-Dxylose using cyclodextrin glycosyltransferase. J. Biochem., 79, 641-648 (1976)

3 ) H. Aga and M. Yoneyama: Synthesis of 2- $O-\alpha$-D-glucopyranosyl L-ascorbic acid by cyclomaltodextrin glucanotransferase from Bacillus stearothermophilus. Agric. Biol. Chem., 55, 17151756 (1991).

4 ) S. Kitahata, S. Okada and A. Misaki: Intermolecular transglycosylation of cyclodextrin glycosyltransferase to D-galactose. Agric. Biol. Chem., 43, 151-154 (1979).

5 ) T. Shibuya, Y. Miwa, M. Nakano, H. Chaen, S. Sakai and M. Kurimoto: Enzymatic synthesis of a novel trisaccharide (glucosyl lactoside). Biosci. Biotechnol. Biochem., 57, 56-60 (1993).

6 ) S. Kitahata, K. Hara, K. Fujita, H. Nakano, N. Kuwahara and K. Koizumi: Acceptor specificity of cyclodextrin glycosyltransferase from Bacillus stearothermophilus and synthesis of $\alpha$-D-glucosyl $O$ - $\beta$-D-galactosyl-(1-4)- $\beta$-D-glucoside. Biosci. Biotechnol. Biochem., 56, 1386-1391 (1992).

7 ) K. Uchida and Y. Suzuki: Enzymatic synthesis of a new derivative of thiamin, $O-\alpha$-glucosylthiamin. Biosci. Biotechnol. Biochem., 62, 221-224 (1998).

8 ) M. Funayama, T. Nishino, A. Hirota, S. Murao, S. Takenishi and H. Nakano: Enzymatic synthesis $(+)$ catechin- $\alpha$-glucoside and its effect on tyrosinase activity. Biosci. Biotechnol. Biochem., 57, 1666-1669 (1993).
9 ) K. Okuda, K. Uchida, M. Sugimoto and S. Suzuki: Transglycosylation to fructose and n-aryl glucoside by CGTase. (in Japanese) Nippon Nogeikagaku Kaishi, 69, p. 27 (1995).

10) T. Kometani, Y. Terada, T. Nishimura, T. Nakae, H. Takii and S. Okada: Acceptor specificity of cyclodextrin glycosyltransferase from an Alkalophilic Bacillus species and synthesis of glucosyl rhamnose. Biosci. Biotechnol. Biochem., 60, 11761178 (1996).

11) S. Mori, M. Goto, H. Tsuji, T. Mase, A. Matsuura, T. Oya and S. Kitahata: Acceptor specificity of cyclodextrin glucanotransferase from Brevibacterium sp. No. 9605 to monosaccharides and phenolic compound. Oyo Toshitsu Kagaku, 44 23-32 (1997).

12) M. Kubota, B. Mikami, Y. Tsujisaka and Y. Morita: Crystallization of and preliminary crystallographic data for Bacillus stearothermophilus cyclodextrin glucanotransferase. J. Biochem., 104, 12-13 (1988).

13) Y. Shiosaka and H. Bunya: Thermostable cyclomaltodextrin glucanotransferase. Proc. Symp. Amylase (in Japanese), 8, 4350 (1973).

14) T. Shibuya, H. Aga, H. Watanabe, T. Sonoda, M. Kubota, S. Fukuda, M. Kurimoto and Y. Tsujisaka: Transglycosylation of glycosyl residues to cyclic tetrasaccharide by Bacillus stearothermophilus cyclomaltodextrin glucanotransferase using cyclomaltodextrin as the glycosyl donor. Biosci. Biotechnol. Biochem., 67, 1094-1100 (2003).

15) S. Somogyi: Notes on sugar determination. J. Biol. Chem., 195, 19-23 (1952).

16) Y. Nakajima: Manufacture and utilization of palatinose. J. Jpn. Soc. Starch Sci., 35, 131-139 (1988).

17) K. Tashiro, T. Iwamasa, H. Kato, S. Ogata and M. Anai: Purification and characterization of two components of acid $\alpha$ glucosidase from pig liver. J. Biochem., 99, 693-701 (1986).

\section{Bacillus stearothermophilus 由来の シクロマルトデキストリングルカノ トランスフェラーゼによるツラノースの製造 \\ 啮谷 孝, 万代隆彦, 久保田倫夫, 福田恵温, 栗本雅司，辻阪好夫 株式会社林原生物化学研究所 （700-0834 岡山市天瀬南町 7-7）}

Bacillus stearothermophilus 由来の CGTase（EC 2.4.1.19） を用いて，フラクトースへの糖転移および糖転移物の生 成条件について検討した. Bacillus stearothermophilus 由来 の CGTase を $\alpha-\mathrm{CD}$ とフラクトースの混合水溶液に作用さ せたところ，一連の糖転移物が生成した。この CGTase 反 応液をグルコアミラーゼで分解したところ，主たる糖転 移物としてッラノースとトレハルロースの生成が認めら れ，CGTase はフラクトピラノースの 3 位と 1 位水酸基に グルコシル転移することがわかった。そこで，主たる糖 転移物のツラノースの最適な生成条件を検討した。その 結果， $30 \% \alpha-\mathrm{CD}$ と $30 \%$ フラクトースの混合水溶液に CGTase を $300 \mathrm{U} / \mathrm{g}-\alpha-\mathrm{CD}, 60^{\circ} \mathrm{C}, \mathrm{pH} 5.5$ で 24 時間作用さ せ，その後グルコアミラーゼ処理することによりツラ ノースは約 $44 \%$ 生成した。 